\title{
Impact of Arenicola marina (Polychaeta) on sediment sulfur dynamics
}

\author{
Ole Ilsøe Nielsen*, Erik Kristensen, Marianne Holmer
}

Institute of Biology, University of Southern Denmark, Campusvej 55, 5230 Odense M, Denmark

\begin{abstract}
Sulfate reduction rates and various parameters related to the sulfur cycling were investigated in situ and experimentally by a mm approach in sediment surrounding burrows of the polychaete Arenicola marina. Sulfate reduction rates were immediately affected in a 5 to $15 \mathrm{~mm}$ thick zone surrounding the tail shaft. Rates were depressed by $52 \%$ in the burrow wall and increased with distance towards ambient rates. Experimental use of artificially ventilated burrows showed that the reduction was mediated by introduction of oxygenated surface water by irrigation, which suppressed possible stimulating effect of increase in organic carbon availability from mucus secretion by the worm. Furthermore, irrigation and sediment reworking by A. marina increased the content of biological reactive Fe(III) in the feeding funnel and in a narrow zone around the tail shaft, creating environments suitable for dissimilative Fe(III) reduction. Total reduced sulfide pools showed that reoxidation of reduced sulfide species occurred along the burrow and in the feeding funnel of $A$. marina. Reoxidation in the tail shaft region was mediated by irrigation, while the reduction in the feeding funnel probably occurred due to the combined effect of irrigation and sediment reworking. In general, A. marina has a great impact on sediment sulfur biogeochemistry, suggesting that bioturbation depresses sulfate reduction and increases the importance of Fe(III) as an electron acceptor in carbon oxidation. It is also indicated that $A$. marina reduces permanent burial of reduced sulfide and lowers the steady-state level of total reduced sulfide in the sediment.
\end{abstract}

KEY WORDS: Bioturbation $\cdot$ Sulfur dynamics $\cdot$ Sulfate reduction $\cdot$ Intertidal sediments $\cdot$ Arenicola marina $\cdot$ Microcosms

Resale or republication not permitted without written consent of the publisher

\section{INTRODUCTION}

Macrozoobenthic activity plays an important role in sediment organic matter decomposition and profoundly affects the geochemistry and microbial processes in coastal sediments (e.g. Andersen \& Kristensen 1988, Aller \& Aller 1998, Banta et al. 1999). Experimental work has shown that macrofaunal activity stimulates total system metabolism in excess of the respiration of the macrofauna. In most cases, the stimulation is caused by increased heterotrophic microbial metabolism. Much research has been conducted to understand the underlying mechanisms for that stimulation, and it is thought they occur through a variety of direct and indirect mechanisms such as burrow irrigation, particle reworking, redox oscillation, excretion and grazing of microbes. The main impacts are probably subduction of labile organic matter from the surface to deeper layers, exposure of new surfaces for microbial colonization (Kristensen 2001), and an enhancement of solute exchange between overlying and pore waters supplying dissolved reactants from the water column to the deeper sediment layer (Aller \& Aller 1998, Furukawa et al. 2000). However, the partitioning of carbon diagenesis into aerobic and anaerobic decomposition is less clear. Increased oxygen exposure of sediment due to burrow walls clearly increases overall oxygen penetration into the sediment, but since oxygen is used in reoxidation of metabolites from anaerobic organic matter decomposition, it is still uncertain to what extent aerobic metabolism is stimulated. Anaerobic degradation pathways are also 
known to be affected, and heterotrophic dissimilative sulfate reduction, iron reduction, and nitrification/ denitrification have all been shown to be altered due to bioturbation (Kristensen et al. 1985, Kostka et al. 2002). Of these, dissimilatory sulfate reduction is considered the most important for carbon mineralization in marine coastal areas (Mackin \& Swider 1989). Early reports of enhanced sulfate reduction in bioturbated sediments were explained by the introduction of labile organic matter to deeper sediment layers by reworking (Aller \& Yingst 1978, Hines \& Jones 1985), a contention supported by Hansen et al. (1996), who observed enhanced sulfate reduction in sediment surrounding the organic-rich burrow walls of Mya arenaria. However, subsequent studies both on natural sediments and in experimental work (Hines et al. 1997, Banta et al. 1999, Kostka et al. 2002) have indicated that infaunal activity decreases the importance of dissimilative sulfate reduction, probably due to enhanced dissimilative Fe(III) reduction and/or aerobic respiration. Solid evidence of partitioning between sulfate and amorphous $\mathrm{Fe}(\mathrm{III})$ as electron acceptors in natural sediments is still lacking, primarily due to methodological limitations in Fe-reduction measurements.

The sediment dweller Arenicola marina, which commonly inhabits the intertidal regions of Northern Europe at densities of 50 to 150 ind $\mathrm{m}^{-2}$, profoundly alters the sediments wherein it lives through particle transport and irrigation activity (Reichardt 1988, Retraubun et al. 1996). It is a head-down deposit feeder situated at 20 to $30 \mathrm{~cm}$ depths in J-shaped and mucuslined burrows. Deep subsurface sediment is ingested from the feeding pocket in front of the lugworm and excreted on the surface, displacing sediment at rates substantially faster than sedimentation from the water column (Cadeé 1976). The burrow is connected to the sediment surface through a vertical tail shaft through which peristaltic movements of the body drive oxygenated surface water in a tail-to-head direction, forcing the irrigated water to exit by percolation in front of the lugworm. Irrigation and particle reworking in combination generate oxidized conditions along the burrow wall, and create a characteristic oxidized feeding funnel in front of the lugworm, which increases total sediment metabolism, decreases permanent sulfide burial, and probably induces electron acceptor partitioning (Banta et al. 1999).

The aim of this study was to examine the relative effects of Arenicola marina burrow structures on sediment sulfur biogeochemistry and to evaluate the impact of bioturbation on sediment microbial metabolism. Profiles of sulfate reduction rates and reduced sulfur pools were measured on a mm scale around $A$. marina burrows under in situ conditions, and compared with experimental microcosm studies on single burrows under controlled laboratory conditions. Artificially ventilated burrows in microcosms were studied to investigate the specific effects of irrigation on sulfur dynamics.

\section{MATERIALS AND METHODS}

Study sites. Sediment and specimens of Arenicola marina were collected from Løgstør Grunde in Limfjorden, Denmark (56 $\left.58^{\prime} \mathrm{N}, 9^{\circ} 16^{\prime} \mathrm{E}\right)$, in April 1995 and from the island of Rømø in the Danish Wadden Sea

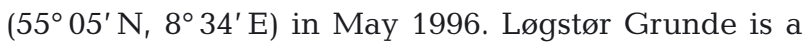
sand flat which is usually water covered, but has prolonged periods of exposure due to wind direction and stowage controlling the water level. The infauna is typical for Danish sand flats and is characterized by deep burrowing filter- and surface deposit-feeding species like A. marina, Mya arenaria, Nereis spp., Corophium volutator and Cerastoderme edule. The salinity was $16 \%$ at sampling. The site at the island of Rømø is a sandy tidal flat, which is air exposed twice daily with a mean tidal range of $\pm 0.85 \mathrm{~m}$. The macrofauna is dominated by $A$. marina $\left(\sim 60 \mathrm{~m}^{-2}\right)$, but other burrowing organisms ( $N$. virens, $M$. arenaria and $C$. volutator) are also observed. Salinity in the area is $32 \%$.

Time series. Since the sulfate reduction rate (SRR) assay was done on small scales and in oxidized sediment, it was considered necessary to perform time series on sediment from the 2 sampling areas to evaluate the precision of the SRR measurements. Vertical profiles of oxidized surface sediment were sampled from both locations by cut-off syringes and immediately sealed with a rubber stopper upon removal. A modified version of the ${ }^{35} \mathrm{SO}_{4}{ }^{2-}$ injection technique (Fossing \& Jørgensen 1989) was used for radial SRR determinations. Radiolabelled sulfate $\left(150 \mathrm{kBq} \mathrm{ll}^{-1}\right)$ was injected through the rubber stopper as a trail along the centre of the syringe core, which ensured minimum exposure to oxygen. The syringe cores from Løgstør Grunde were incubated for 30, 60 and $120 \mathrm{~min}$ before termination and distillation, while sediment from Rømø was incubated for 15, 20, 25, 30 and $40 \mathrm{~min}$. Cores from both locations were sliced into 3 sections of increasing thickness with depth $(5,10$ and $15 \mathrm{~mm})$, and transferred into $20 \%$ zinc acetate. Subsequently, the sediment was distilled by the single-step distillation procedure (Fossing \& Jørgensen 1989). Aliquots of labelled pore water and trapped sulfide were radioassayed on a scintillation counter (Packard 2200CA). Pore water for sulfate analysis was obtained from the sediment by centrifugation $(1000 \times g, 5 \mathrm{~min})$ and preserved by addition of $0.1 \mathrm{M} \mathrm{HCl}$. Sulfate was later analyzed on a HPLC-anion chromatograph with suppressor (AMMS), with an IonPac AS4A-SC column and 
AG4A guard column after dilution (1:20). Sediment was sampled and sliced as described for SRR analysis.

In situ measurements. Sediment sampling for in situ measurements was carried out at Løgstør Grunde on the air exposed sand flat by removing full burrow systems from the sediment. Radial sediment samples were taken at 3 depths ( 2 to 3,10 to 12 and $>17 \mathrm{~cm}$ ) on 7 burrows by forcing tip-cut $5 \mathrm{ml}$ syringes horizontally from Arenicola marina burrow walls into the sediment. The syringes were immediately sealed with a rubber stopper upon removal and brought back to the laboratory. The modified version of the ${ }^{35} \mathrm{SO}_{4}{ }^{2-}$ injection technique (Fossing \& Jørgensen 1989), described previously, was used for radial SRR determinations. Cores were incubated for 25 to $30 \mathrm{~min}$ at in situ temperature $\left(\sim 15^{\circ} \mathrm{C}\right)$ in darkness, and terminated by placing the syringes in a $-12^{\circ} \mathrm{C}$ saturated saltwater-ice solution. Subsequently, the sediment was sliced into 2 (0 to $12 \mathrm{~mm}$ ) and $5 \mathrm{~mm}$ sections (12 to $32 \mathrm{~mm}$ ) and immediately distilled as described previously. Subsamples of the trapped sulfide from the distillations were used for determination of total reduced sulfur (TRS) and analyzed spectrophotometrically by the methylene blue technique as described by Cline (1969).

Sediment for vertical profiles of SRR and TRS were collected from the sampling area in transparent sediment core tubes $(2.8 \mathrm{~cm}$ inner diameter) with siliconefilled injection ports (spacing $1 \mathrm{~cm}$ ). Sediment cores for ambient parameters were collected from areas that appeared the least disturbed by the activity of Arenicola marina. For vertical SRR determination, $2 \mu \mathrm{l}$ of ${ }^{35} \mathrm{SO}_{4}{ }^{2-}$ tracer $\left(60 \mathrm{kBq} \mathrm{ll}^{-1}\right)$ was injected as a spot injection every $\mathrm{cm}$. The cores were incubated for $4 \mathrm{~h}$ at $15^{\circ} \mathrm{C}$ in darkness, and subsequently sliced into $1(0$ to $6 \mathrm{~cm})$ and $2 \mathrm{~cm}$ sections (6 to $16 \mathrm{~cm}$ ). All sections were transferred into $20 \%$ (w/w) zinc acetate to terminate the incubation and preserve them, and later distillation and analysis occurred, as previously described.

Microcosm studies. Sediment for the experimental part of the study was collected at the island of Rømø, sieved through a $1 \mathrm{~mm}$ mesh at the location, and brought back to the laboratory where it was kept in fully oxygenated seawater from the location (diluted to $16 \%$ with distilled water) and at a constant temperature $\left(15^{\circ} \mathrm{C}\right)$. Experimental 'sandwich' chambers made of transparent Plexiglas $(30 \times 25 \times 0.8 \mathrm{~cm})$ were used to measure radial profiles of SRR, TRS, solid phase Fe compounds, dissolved $\mathrm{Fe}^{2+}$ and porosity along the sediment surrounding the tail shaft. From the same chambers, vertical profiles were obtained in the feeding funnel and in ambient sediment surrounding the Arenicola marina burrows (Fig. 1). The chambers were designed with silicon-filled injection ports (spacing $1 \mathrm{~cm}$ ) on each side and with a detachable front, attached to the chamber by screws. Prior to the exper- iments, chambers were filled with sieved and homogenized sediment and left for compaction for $7 \mathrm{~d}$ at $15^{\circ} \mathrm{C}$ in diluted (salinity $16 \%$ ) oxygen-saturated seawater from the location. Subsequently, 1 lugworm (approximately 3 to $4 \mathrm{~g}$ wet wt) was added each chamber and allowed $5 \mathrm{~d}$ to establish a burrow. Due to limited sediment volume in each chamber, separate chambers were used for each parameter. For later discussion and analysis, all used burrow systems were considered comparable and equal.

Radial SRR in sediment surrounding the tail shaft were measured by injecting ${ }^{35} \mathrm{SO}_{4}{ }^{2-}$ tracer $(240 \mathrm{kBq}$ per $45 \mu \mathrm{l}$ ) as a horizontal trail from the tail shaft into the ambient sediment at 3 different depths $(3,7$ and $14 \mathrm{~cm})$. Vertical profiles were obtained by spot injection of $10 \mu \mathrm{l}$ of radiolabelled tracer $\left(10 \mathrm{kBq} \mathrm{ll}^{-1}\right)$ for every $\mathrm{cm}$ in the feeding funnel and in ambient sediment. The chambers were incubated for $30 \mathrm{~min}$ in darkness and terminated by immersion in a cold $\left(-12^{\circ} \mathrm{C}\right)$ saturated saltwater solution, which froze all parts of the chamber within $3 \mathrm{~min}$. The front of the chamber was subsequently detached and the radiolabelled sediment was sampled while still frozen. Horizontal profiles from the tail shaft were sectioned into $2 \mathrm{~mm}$ intervals from 0 to $6 \mathrm{~mm}, 3 \mathrm{~mm}$ intervals from 6 to $12 \mathrm{~mm}, 5 \mathrm{~mm}$ intervals from 12 to $22 \mathrm{~mm}$ and $10 \mathrm{~mm}$ intervals from 22 to $32 \mathrm{~mm}$, added into $10 \mathrm{ml}$ of $50 \%$

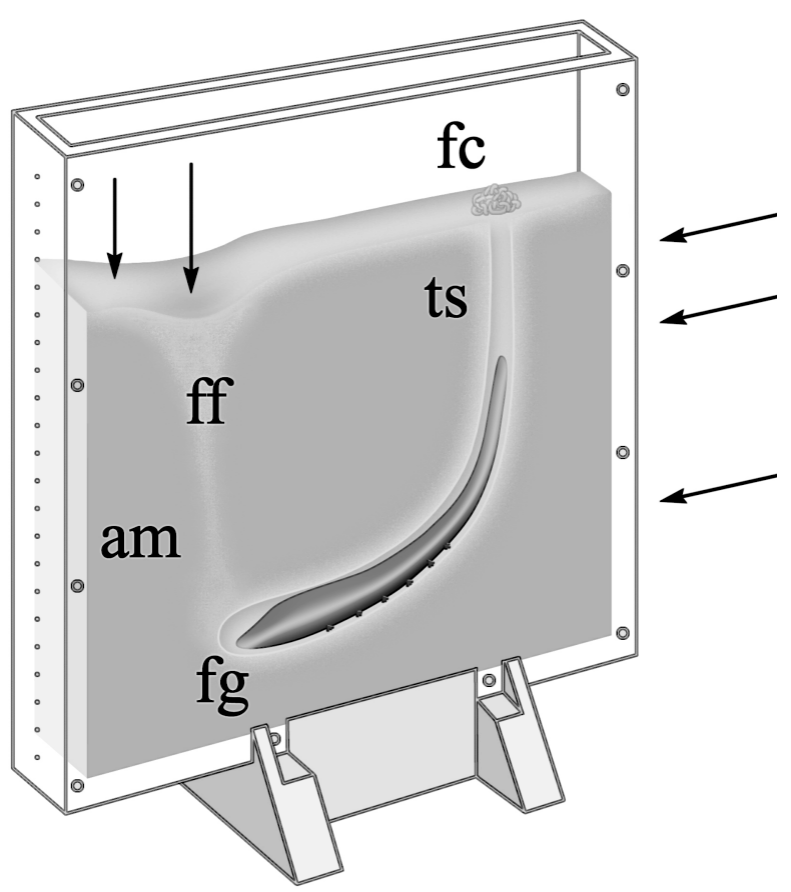

Fig. 1. Illustration of 'sandwich' chambers used for experiments with Arenicola marina and artificial tubes (ts = tail shaft, ff $=$ feeding funnel, $f g=$ feeding gallery, $\mathrm{fc}=$ faecal cast $\mathrm{am}=$ ambient sediment). Arrows indicate injection sites 
ethanol, and distilled according to Fossing \& Jørgensen (1989). Vertical profiles were cut into $1 \mathrm{~cm}$ sections and transferred into $20 \%$ zinc acetate for preservation. The sediment was later distilled according to Fossing \& Jørgensen (1989), and analyzed for SRR and TRS as previously described.

Pore water for sulfate, free sulfide analysis and dissolved $\mathrm{Fe}^{2+}$ was extracted from the sediment in $\mathrm{N}_{2}$ atmosphere. To obtain a sufficient quantity of pore water, sediment from each interval was pooled along the tail shaft down to $15 \mathrm{~cm}$ and centrifuged $(1000 \times g$, $5 \mathrm{~min}$ ). Subsamples for free sulfide were immediately transferred to $5 \%$ zinc acetate for preservation and later analyzed according to Cline (1969). Extracted pore water for $\mathrm{Fe}^{2+}$ was immediately added into Ferrozin and later analyzed spectrophotometrically. The remaining pore water was added to $0.5 \mathrm{M} \mathrm{HCl}$ for preservation and used for sulfate analysis.

Chambers for the determination of horizontal and vertical profiles of HCl-extractable Fe(III), total Fe (tot$\mathrm{Fe}$ ), dissolved $\mathrm{Fe}$ and porosity profiles were prepared and sectioned as described for SRR determinations, but without freezing. Particulate iron pools were measured spectrophotometrically after the Ferrozine procedure described by Lovley \& Phillips (1987). Sediment subsamples from each interval were transferred to $1 \mathrm{M}$ $\mathrm{HCl}$ and extracted for $1 \mathrm{~h}$. Samples of the extractant were transferred to Ferrozine for Fe(II) determination (Stookey 1970). The total reactive iron pool was determined by adding hydroxyl ammonium chloride to aliquots of the sample extractions in order to reduce Fe(III) pools, and subsequently analyzed by Ferrozine. The difference between tot-Fe and Fe(II) was defined as reactive Fe(III) (Kostka \& Luther 1994).

Artificially irrigated burrows were constructed to determine the impact of irrigation on sulfur biogeochemistry. J-shaped perforated PVC tubes covered by an oxygen-permeable dialysis tube (Spectrapor\#1) were placed in the 'sandwich' chambers and covered by sediment to create an artificial Arenicola marina burrow without mucus lining. Oxygenated seawater (salinity $\sim 16 \%$, temperature $15^{\circ} \mathrm{C}$ ) was pumped from a reservoir and into the artificial burrow through a Pasteur pipette. The rate of irrigation was maintained at $2 \mathrm{ml} \mathrm{min}-1$, which equals the ventilation rate of a $3 \mathrm{~g}$ lugworm (Zebe \& Schiedek 1996). The artificial burrows were constructed $5 \mathrm{~d}$ before irrigation started, which lasted for $4 \mathrm{~d}$. During the pre-irrigation period no changes in sediment color were observed, while a distinct oxidized zone, similar to that of natural burrows, was established within $1 \mathrm{~d}$ of irrigation. Determination of SRR and TRS was performed as described above for $A$. marina burrows. Particulate and dissolved iron was not determined in these chambers due to methodological problems.
Sediment characteristics. Sediment characteristics were measured on pooled sediment due to limited sediment volume. Density was determined as weight of known sediment volume, and sediment water content was determined as water loss after drying for $12 \mathrm{~h}$ at $105^{\circ} \mathrm{C}$. Subsamples of the dried sediment were used for organic content determination following loss-onignition (LOI) at $520^{\circ} \mathrm{C}$ for $6 \mathrm{~h}$, in accordance with the procedure of Kristensen \& Andersen (1987).

\section{RESULTS}

\section{General observations}

Sediment cores collected at Løgstør Grunde showed a brownish oxidized zone in the upper 1 to $2 \mathrm{~cm}$ overlying reduced and greyish sediment with irregular black spots. The sediment appeared sandy with a mean organic matter content (LOI) of $0.40 \pm 0.04 \%$ dry wt $(\mathrm{n}=27$ ) and a porosity of 0.35 to 0.41 . Faunal activity was evident as local extension of the oxidized surface deep into the sediment. Arenicola marina burrows were clearly visible when removed from the sediment as a thick reddish mucus lining followed by a thin oxidized zone of brownish sediment.

Observations in the 'sandwich' chambers indicated that Arenicola marina fed and defecated well throughout the experimental period. A reddish/yellow color the sediment surface appeared within $1 \mathrm{~d}$, and the feeding funnel became visible as light grey sediment within 2 to $3 \mathrm{~d}$ after addition of the worm. The sediment used was sandy and homogeneous with a mean LOI of $0.38 \pm 0.05 \%$ dry wt $(n=27)$ and porosity ranging from 0.30 to 0.35 . Sediment in the vicinity of the tail shaft was more porous than ambient sediment, with values at 0.45 in the burrow wall gradually decreasing to ambient values ca. $12 \mathrm{~mm}$ from the burrow (data not shown).

The artificial irrigation system functioned flawlessly and ventilated the system throughout the experiment. A light-brown colored sediment developed around the artificial burrow within $1 \mathrm{~d}$, as observed around natural burrows.

\section{Time-series incubations}

Both time series showed decreasing rates with time, indicating reoxidation of labelled sulfide (Fig. 2). The mean SRR in sediments from Løgstør Grunde (Fig. 2a) showed a significant $(p<0.005) 3$-fold decrease from 60 to $120 \mathrm{~min}$ of incubation in all 3 investigated sections, but no significant differences were observed at longer incubation times. Mean SRR in sediments from 


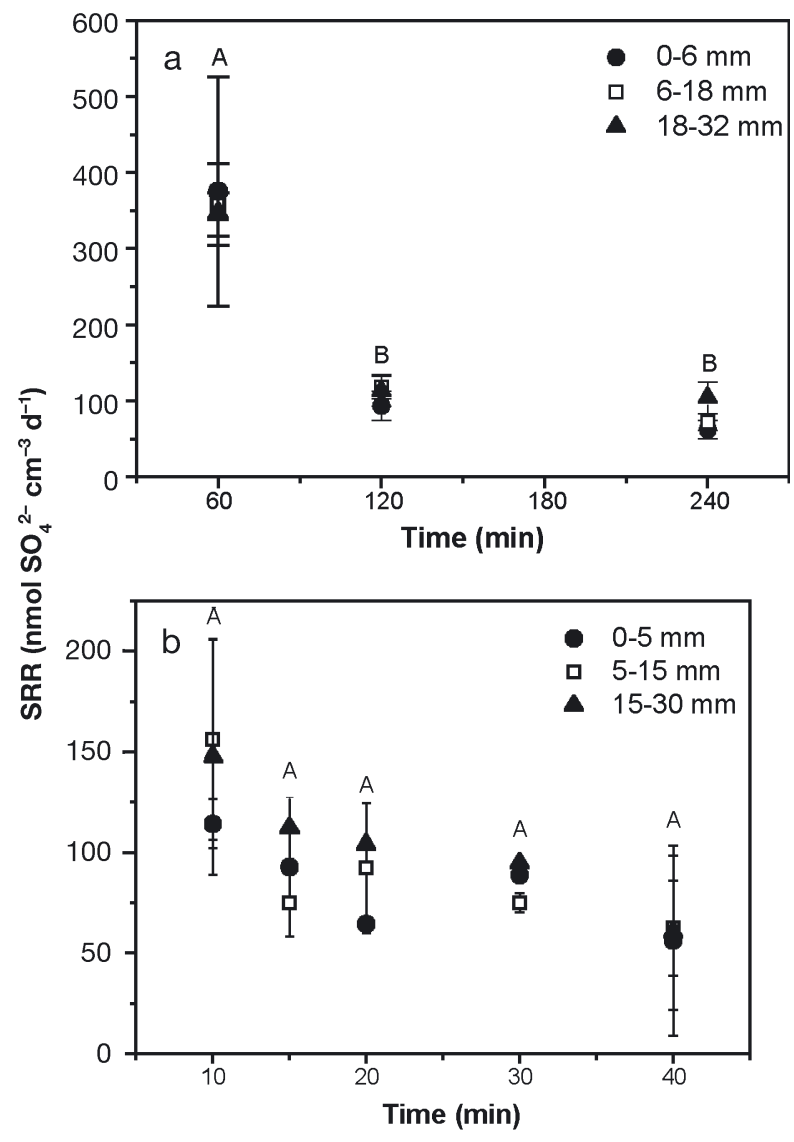

Fig. 2. Time course series of sulfate reduction rates (SRR) at 3 depths in oxidized surface sediment from (a) Løgstør Grunde, and (b) Rømø. Values are presented as (a) mean \pm SE $(n=4)$ and $(b)$ mean \pm range $(n=2)$

Rømø showed a 3-fold decrease from 10 to $40 \mathrm{~min}$ of incubation in all analyzed intervals (Fig. 2b). However, due to large variations in the small sampling sizes $(n=3)$, the decreases were not significant $(p>0.05)$.

\section{Vertical profiles}

Vertical rates of sulfate reduction exhibited a distinct surface maximum of $690 \mathrm{nmol} \mathrm{cm}{ }^{-3} \mathrm{~d}^{-1}$, follow by a sharp decline to $330 \mathrm{nmol} \mathrm{cm} \mathrm{c}^{-3} \mathrm{~d}^{-1}$ at $2 \mathrm{~cm}$ depth in sediment from Løgstør Grunde. Below this depth, rates gradually decreased to become constant at ca. $100 \mathrm{nmol} \mathrm{cm}^{-3} \mathrm{~d}^{-1}$ at $7 \mathrm{~cm}$ depth. TRS gradually decreased with depth from $9 \mu \mathrm{mol} \mathrm{cm} \mathrm{cm}^{-3}$ in the surface sediment to $5 \mu \mathrm{mol} \mathrm{cm} \mathrm{cm}^{-3}$ at $16 \mathrm{~cm}$ depth (Fig. 3).

Considerable variations in vertical SRR were observed in the ambient sediment from the chamber experiment. SRR was 3 to 10 times lower than in situ rates, and almost constant with depth $(26$ and $55 \mathrm{nmol}$ $\mathrm{cm}^{-3} \mathrm{~d}^{-1}$ ), with no subsurface peaks (Fig. 4a). The variability among replicates in SRR in the feeding funnel was also large, but rates were constantly lower than in ambient sediment. Rates were almost constant with depth (12 to $19 \mathrm{nmol} \mathrm{cm}^{-3} \mathrm{~d}^{-1}$ ), although a small subsurface peak of $31 \mathrm{nmol} \mathrm{cm}^{-3} \mathrm{~d}^{-1}$ was evident from 2 to $7 \mathrm{~cm}$ depth. Ambient TRS content remained almost constant with depth at 13 to $17 \mu \mathrm{mol} \mathrm{cm}{ }^{-3}$, while TRS content in the feeding funnel was $16 \%$ lower than ambient levels, on average varying between 10.5 and $16 \mu \mathrm{mol} \mathrm{cm}^{-3}$ (Fig. 4b).

The vertical pools of total $\mathrm{HCl}$ extractable iron (tot$\mathrm{Fe}$ ) in the chamber experiments were constant with depth $\left(\sim 5.5 \mu \mathrm{mol} \mathrm{g}^{-1}\right.$ wet wt), except for a surface peak of $6.6 \mu \mathrm{mol} \mathrm{g}^{-1}$ wet wt (Fig. 4c). Reactive Fe(III) in ambient sediment was high in the upper sediment layer $\left(2.6 \mu \mathrm{mol} \mathrm{g}^{-1}\right.$ wet wt), but rapidly decreased with depth to $<1 \mu \mathrm{mol} \mathrm{g}^{-1}$ wet wt at $2 \mathrm{~cm}$ and below. Fe(III) content was enriched in the upper $6 \mathrm{~cm}$ of the feeding funnel relative to ambient sediments, with a pool of $3.9 \mu \mathrm{mol} \mathrm{g}^{-1}$ wet wt in the top $1 \mathrm{~cm}$ that gradually decreased to the background level $\left(<1 \mu \mathrm{mol} \mathrm{g}^{-1}\right.$ wet wt) at $6 \mathrm{~cm}$ and below. The background Fe(III) measured at depth is probably due to extraction of nonreactive iron (crystalline) employed by the $\mathrm{HCl}$ extraction procedure (Canfield 1989).

Dissolved pore-water $\mathrm{Fe}^{2+}$ was present at all depths and increased from $20 \mu \mathrm{M}$ at the surface to $200 \mu \mathrm{M}$ at $2 \mathrm{~cm}$ and below (Fig. 4d).

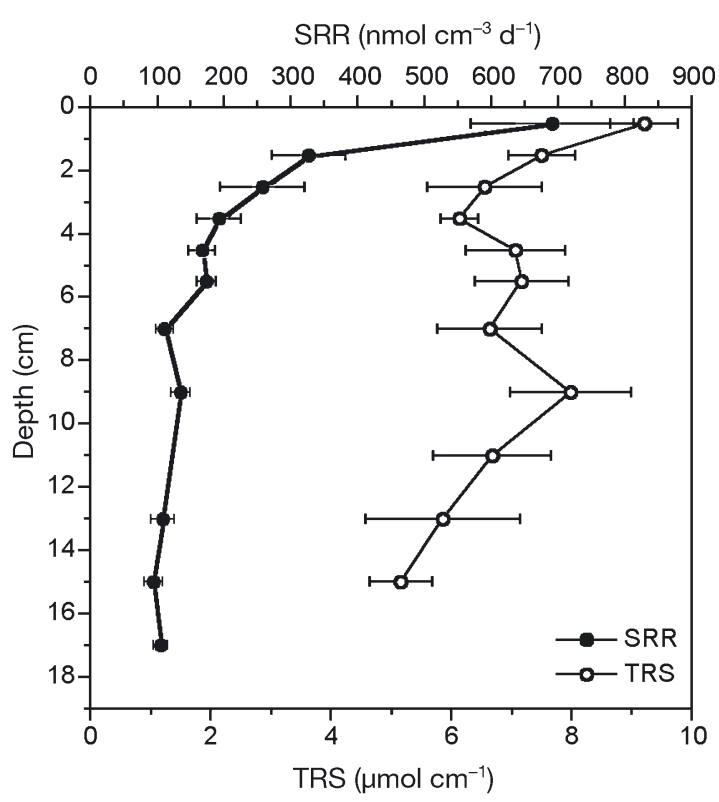

Fig. 3. Vertical profiles of sulfate reduction rates (SRR) and total reduced sulfur (TRS) in sediment from Løgstør Grunde. Values presented as mean $\pm \mathrm{SE}(\mathrm{n}=4)$ 


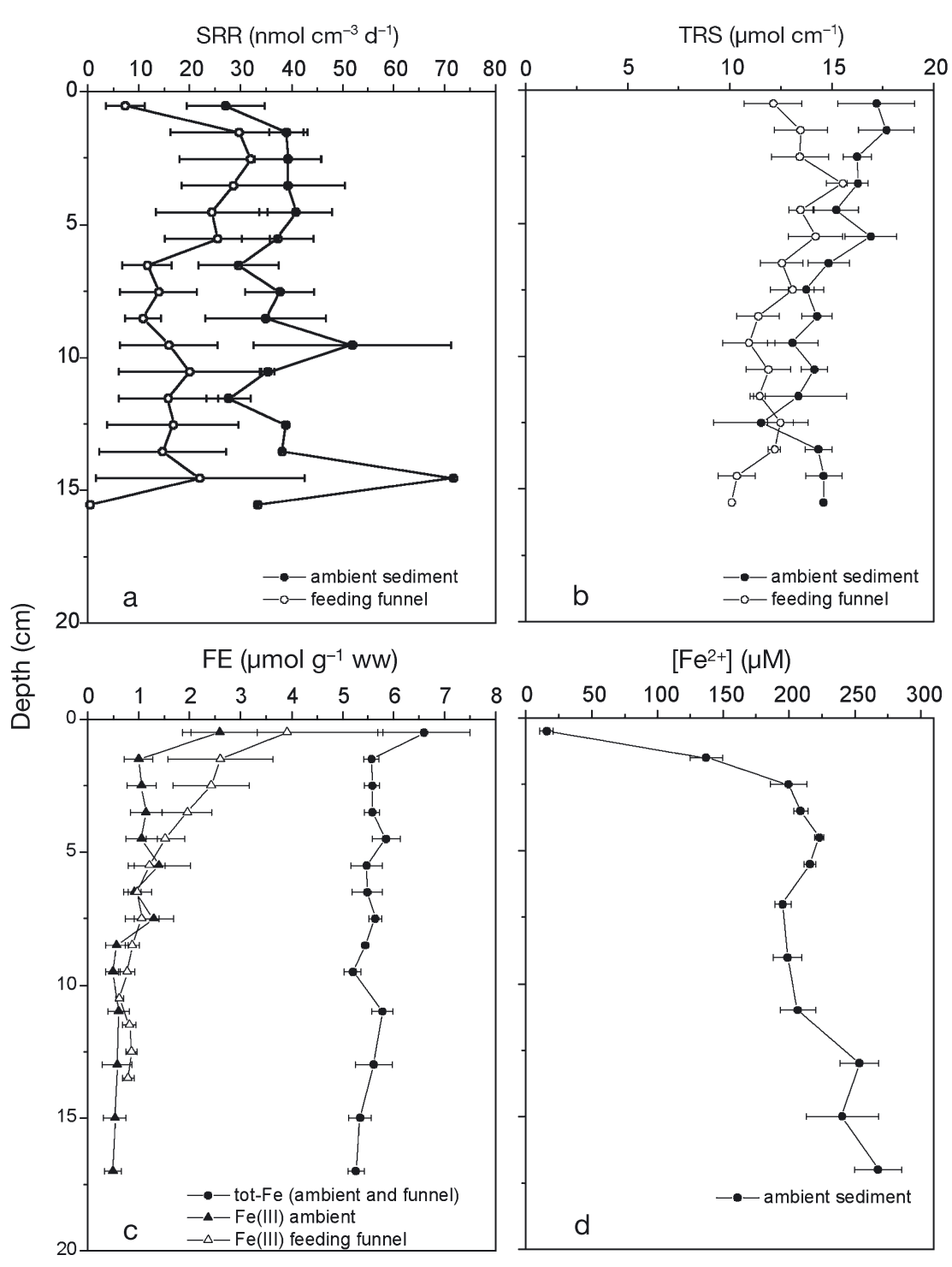

Fig. 4. Vertical profiles of (a) sulfate reduction rates (SRR), (b) total reduced sulfur (TRS), (c) particulate Fe pools and (d) dissolved $\mathrm{Fe}^{2+}$ in sediment from 'sandwich' chambers (mean $\pm \mathrm{SE}, \mathrm{n}=4$ )

\section{Radial profiles}

Radial profiles of SRR in the sediment surrounding Arenicola marina burrows were relatively consistent between in situ and chamber experiments (live worms and artificially irrigated burrows) (Fig. 5), showing depressed SRR in the sediment nearest the burrow gradually increasing with distance. In situ measurements showed depressed rates in a 2 to $12 \mathrm{~mm}$ zone, followed by a gradual 3.5- to 4 -fold increase towards the levels observed in the vertical profiles (Fig. 5).

Radial SRR profiles in chamber experiments with live Arenicola marina increased 2- to 4.5-fold with distance, with a peak at 7.5 to $17.5 \mathrm{~mm}$. Rates gradually decreased after the peak (Fig. 5). It is noticeable that radial rates were always larger than ambient levels, although rates seemed to reach a stable level before $30 \mathrm{~mm}$. However, this difference is not believed to be real, but is probably due to methodological inconsistencies between the injection and distillation procedure used. The distance to which the burrow wall affected SRR was independent of vertical depth in the sediment, in both the in situ and chamber experiments.

Radial SRR profiles obtained from 7 and $17 \mathrm{~cm}$ in the artificial burrow experiment were similar to SRR profiles with Arenicola marina. Rates peaked at 5 to $12 \mathrm{~mm}$, with 4 - to 5-fold higher rates than those near the burrow (Fig. 5). However, the profile at $3 \mathrm{~cm}$ did not follow the general pattern of depressed rates in the burrow wall. A closer look revealed a large variation in the sediment data juxtaposed to the burrow, probably reflecting irregularities and interference in the transition between the artificial burrow wall and surface sediment.

Radial TRS profiles were generally consistent with the SRR profiles, and showed low pools near the burrow wall, which gradually increased with distance. This pattern was least pronounced in the in situ measurements, where a large variation disturbed the general trend, although reduced pools were always evident near the burrow wall (Fig. 6). Lower TRS pools near the burrow walls were more distinct in the chamber experiments, where the pools were reduced by 30 to $60 \%$ (Fig. 6). An ambient level was reached 7.5 to $15 \mathrm{~mm}$ from the burrow wall, independent of the sediment depth. The artificially irrigated burrows were affected similarly, with reduced pools in a 7.5 to $15 \mathrm{~mm}$ zone surrounding the burrow, with no evident effect of depth (Fig. 6).

Radial profiles of total Fe and reactive Fe(III) measured in experimental chambers containing Arenicola marina are shown in Fig. 7. Burrow irrigation only affected reactive $\mathrm{Fe}(\mathrm{III})$ in a thin $2 \mathrm{~mm}$ zone adjacent to the burrow wall, where the pool was enriched from background levels at $<1$ to $2.0-2.8 \mu \mathrm{mol} \mathrm{g}{ }^{-1}$ wet wt. Total extracted Fe only varied slightly with distance, remaining at a level comparable to ambient level. Due to limited amounts of pore water, radial profiles of dissolved $\mathrm{Fe}^{2+}$ could not be specified to defined depths. Instead, pore water was pooled along the burrow to 
Depth: $3 \mathrm{~cm}$
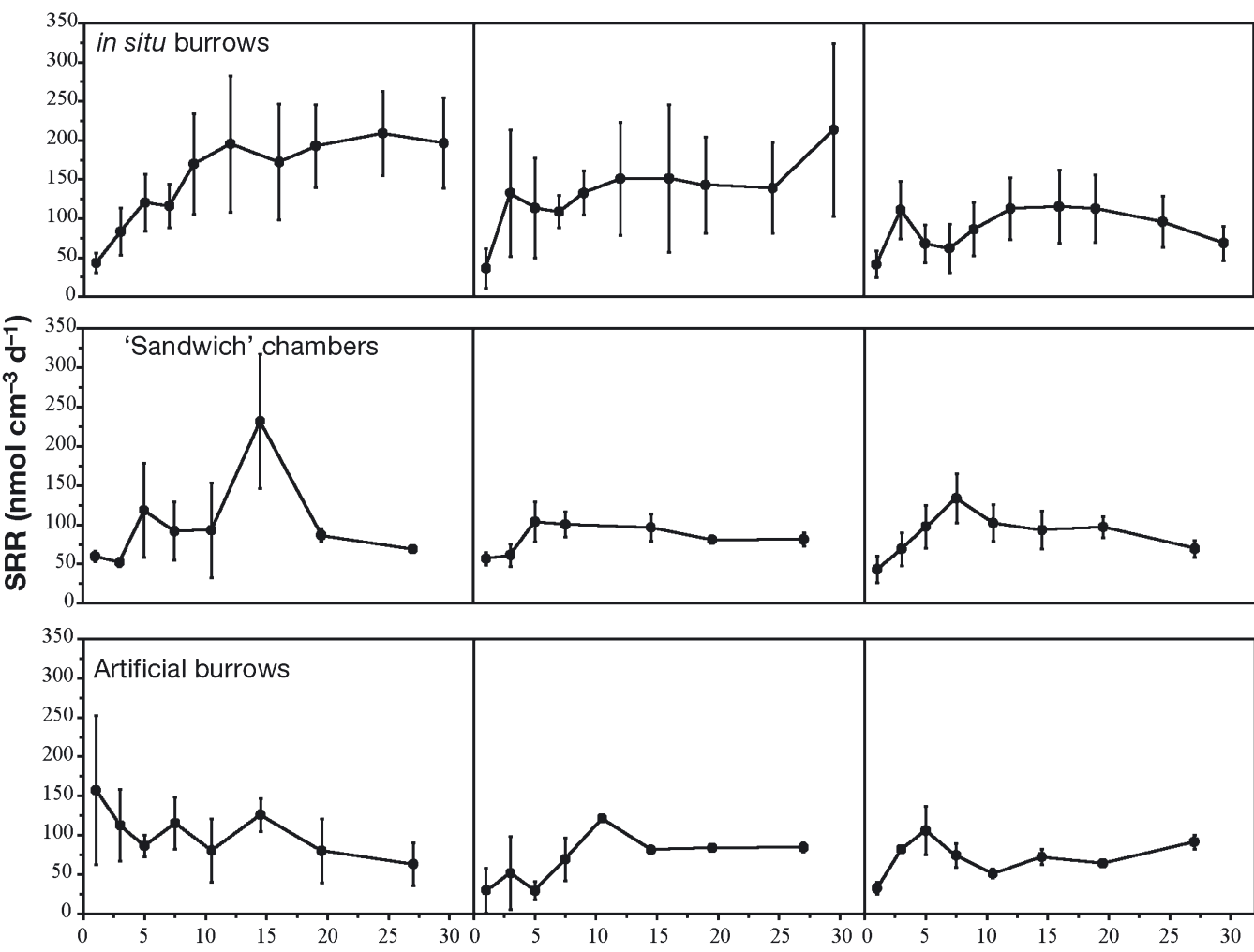

Depth: $12 \mathrm{~cm}$

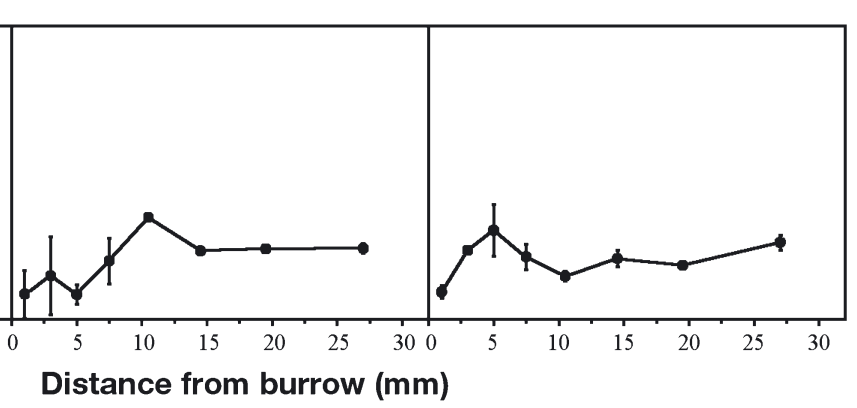

Fig. 5. Radial profiles of sulfate reduction rates (SRR) in sediment surrounding the tail shaft of natural and artificial Arenicola marina burrows. Top row represents profiles from Løgstør Grunde, middle row from 'sandwich' chamber experiments with live A. marina, and lower row from artificial burrows in chambers. Samples are taken from 3 depths $(3,7$ and $>17 \mathrm{~cm})$. Values are presented as mean $\pm \mathrm{SE}$ ( $\mathrm{n}=5, \mathrm{n}=4$ and $\mathrm{n}=4$, respectively). tot- $\mathrm{Fe}=$ total $\mathrm{Fe}$

Depth: $3 \mathrm{~cm}$

Depth: $12 \mathrm{~cm}$

Depth: $17 \mathrm{~cm}$

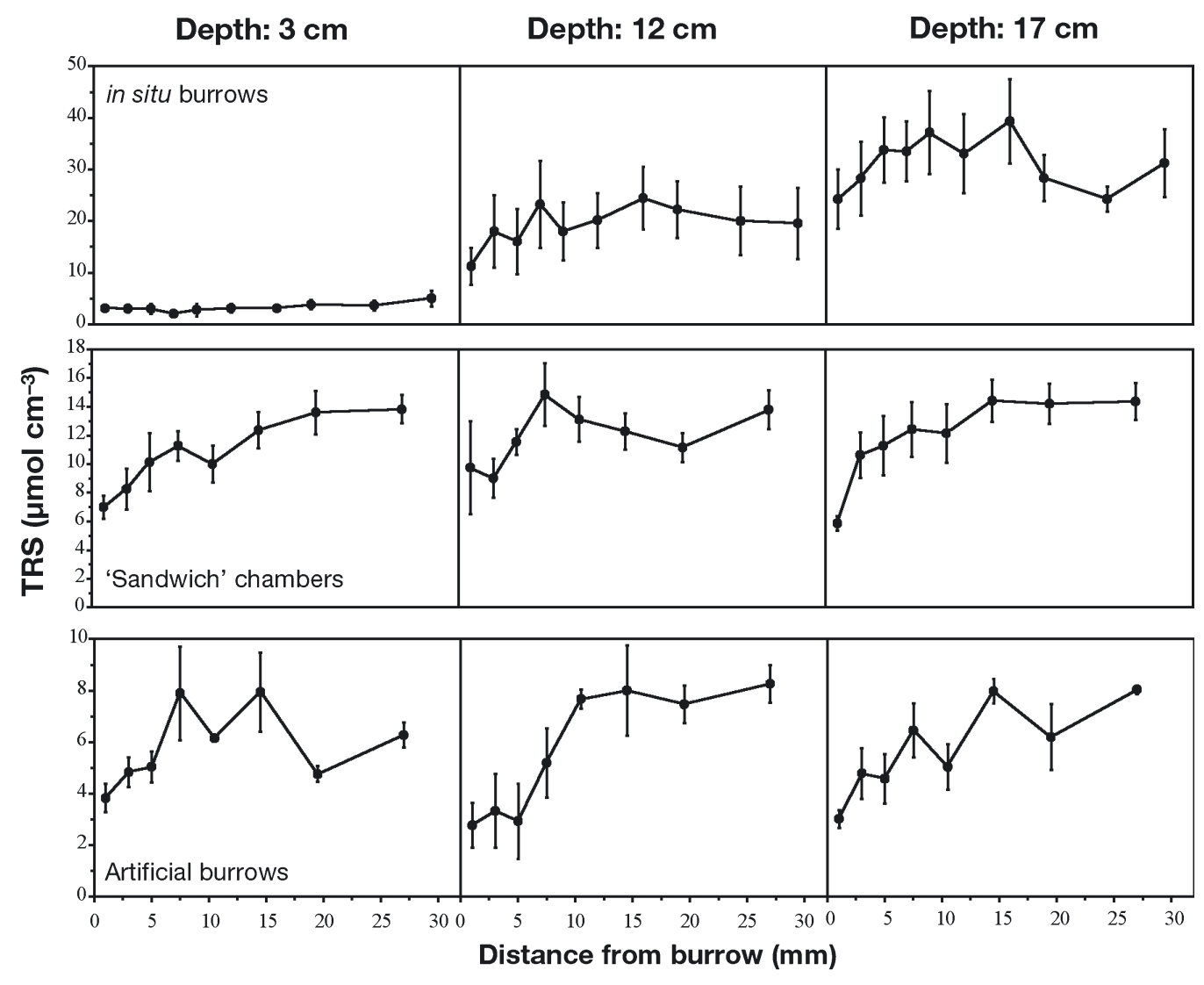

Fig. 6. Radial profiles of total reduced sulfur (TRS) in sediment surrounding the tail shaft of natural and artificial Arenicola marina burrows. Top row represents profiles from Løgstør Grunde, middle row from 'sandwich' chamber experiments with live A. marina, and lower row from artificial burrows in chambers. Samples are taken from 3 depths $(3,7$ and $>17 \mathrm{~cm})$. Values are presented as mean $\pm \mathrm{SE}$ ( $\mathrm{n}=5, \mathrm{n}=4$ and $\mathrm{n}=4$, respectively) 


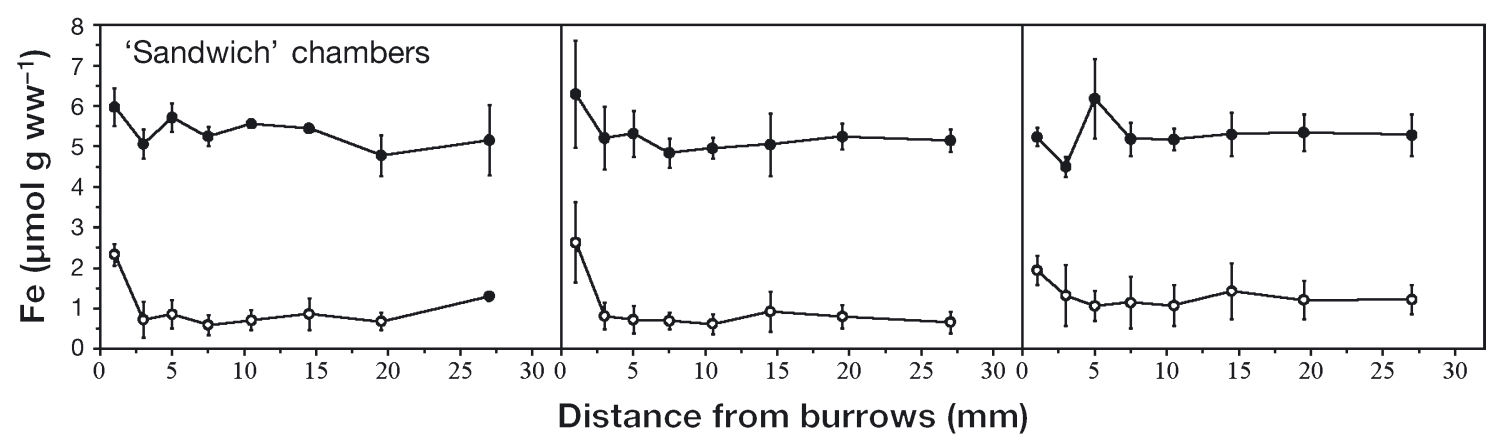

Fig. 7. Radial profiles of particulate Fe pools in sediment surrounding the tail shaft of Arenicola marina burrows in 'sandwich' chambers. Samples are taken from 3 depths $(3,7$ and $>17 \mathrm{~cm})$. Values are presented as mean $\pm \operatorname{SE}(n=4)$

represent a mean concentration. Fig. 8 shows that $\mathrm{Fe}^{2+}$ was present at all distances from the burrow, and increased rapidly from $25 \mu \mathrm{M}$ near the burrow to 150 to $250 \mu \mathrm{M}$ at $5 \mathrm{~mm}$, and remained constant at the ambient level (Fig. 8).

\section{DISCUSSION}

Comparison of sediments and sediment metabolism from different locations can be difficult due to their unknown history and heterogeneous structure. Furthermore, mixing and homogenization of sediment clearly destroys the natural chemical, physical and biological structure of sediments (Kristensen \& Blackburn 1987, van Duyl et al. 1992). Although the 2 locations used in this study were chosen for their similarities, they were evidently 2 different sediments with different biogeochemical activities, solid particulate sulfur and reactive iron pools. It was also obvious that our experimental approach 'flattened' vertical profiles in ambient sediment from ex situ experiments compared to natural profiles, hence not allowing us to compare

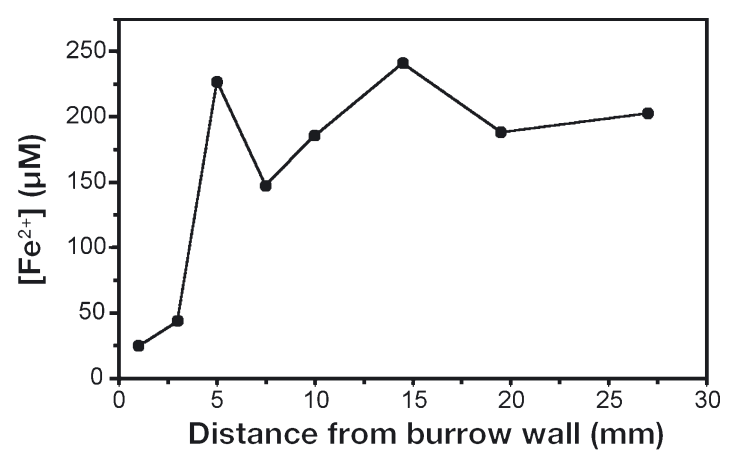

Fig. 8. Radial profile of pore-water $\mathrm{Fe}^{2+}$ from tail shaft of Arenicola marina burrow. Each point represents pooled sediment from 3 chambers with $A$. marina absolute rates and pool sizes obtained from in situ and ex situ experiments. However, microcosm studies with homogenized sediments have, in previous studies, proven useful in illustrating general principles in sediment biogeochemistry, as natural variability is minimized, reproduction is easy, and the initial conditions can be described (Meyers et al. 1988, Kampichler et al. 2001). The high similarity between profiles obtained in situ and ex situ indicates that relative changes in rates and pools sizes were comparable between the 2 sediments used, and that microcosm studies were useable tools in describing the impact of Arenicola marina on the cycling of sulfur.

A major obstacle often associated with measurements of sulfate reduction rates in oxidized sediments is reoxidation of produced radiolabelled sulfide, and hence rate underestimation. As the investigated burrow walls were directly affected by oxygen, measurements in this compartment were especially subjected for underestimation, since produced radiolabelled sulfide easily reacts with oxygen and is reoxidized back to sulfate. While SRR decreased significantly from 1 to $2 \mathrm{~h}$ of incubation in the in situ measurements, and hence showed fast reoxidation rates, the artefact was apparently avoided in the chamber experiment, where measurements of SRR were independent of incubation times between 10 and $40 \mathrm{~min}$. However, it was evident that the transfer rate of ${ }^{35} \mathrm{SO}_{4}{ }^{2-}$ to $\mathrm{H}^{35} \mathrm{~S}^{-}$only approached linearity at incubation times longer than 10 min (Fig. 9). According to the model by Moeslund et al. (1994), transfer initially occurred at faster rates (0 to $10 \mathrm{~min}$ ), which indicates rapid reoxidation of radiolabelled $\mathrm{H}^{35} \mathrm{~S}^{-}$even at short incubations times, showing the initial gross SRR to be 4 to 8 times higher than the measured net SRR (Table 1). The underestimation suggests that SRR is more important for organic carbon diagenesis in both sediments than the measured values indicate. Hence, comparison of absolute SRR between in situ and ex situ experiments must be 
avoided due to this large uncertainty. However, reoxidation occurred with equal rates in all investigated sediment layers. The impact on the relative changes in SRR is probably limited, which makes it possible to compare profiles from all depths and between in situ and ex situ experiments.

\section{Effect of Arenicola marina on sulfur dynamics}

Infaunal activity is generally known to stimulate both total benthic and microbial metabolism through irrigation, particle reworking, excretion and grazing of microbes (e.g. Aller 1988, Kristensen 2001). How bioturbation affects aerobic and anaerobic metabolism separately is only partly investigated, but it is clear that important physio-chemical parameters like diffusion affect aerobic and anaerobic metabolism differently. Irrigation in particular promotes conditions for aerobic degradation through an increased sediment-water surface, across which oxygen can diffuse (Binnerup et al. 1992, Furukawa et al. 2000), although Aller \& Aller (1998) recently found experimental evidence for increased anaerobic metabolism with increased density of burrowing infauna (decreasing diffusion distances), the reasons for which are still unknown. The present in situ study clearly demonstrated that burrowing activity by Arenicola marina introduced oxidized microniches along the burrow walls and into the otherwise anoxic sediment, which on average reduced SRR by 27 to $45 \%$ in a 5 to $15 \mathrm{~mm}$-thick zone. Aller \& Yingst (1980) and Hines \& Jones (1985) claimed that flushing and introduction of labile organic matter deep into the

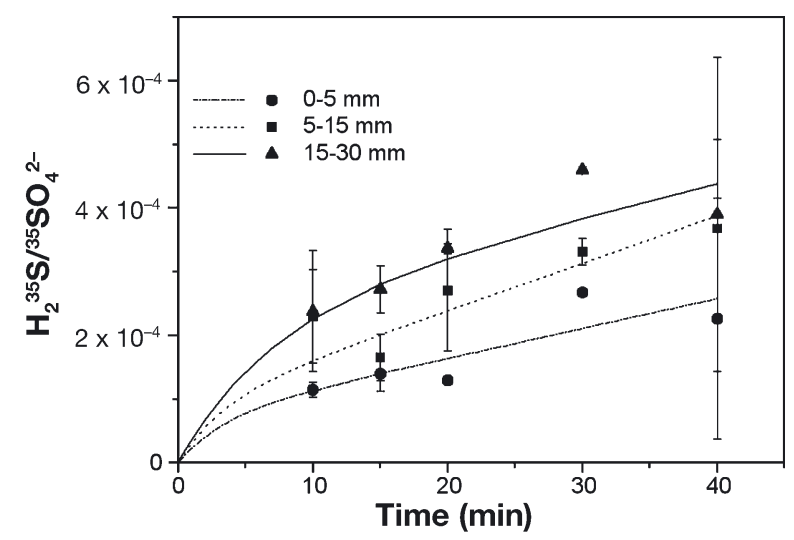

Fig. 9. Development in relative activity $\left(\mathrm{H}_{2}{ }^{35} \mathrm{~S} /{ }^{35} \mathrm{SO}_{4}{ }^{2-}\right)$ at 3 depths in oxidized surface sediment from Rømø. Fitted curves represent best fit to the equation: $\mathrm{F}=\mathrm{a}+\mathrm{bx}+\mathrm{ae}^{-\mathrm{kt}}$, where $\mathrm{F}=\mathrm{TRI}^{35} \mathrm{~S} /{ }^{35} \mathrm{SO}_{4}{ }^{2-}, \mathrm{a}=$ or $/(\mathrm{o}+\mathrm{p}) 2, \mathrm{~b}=\mathrm{pr} /(\mathrm{o}+\mathrm{p}), \mathrm{k}=$ $\mathrm{o}+\mathrm{p}, \mathrm{r}=$ gross ${ }^{35} \mathrm{SO}_{4}{ }^{2-}$ reduction rate, $\mathrm{o}=\mathrm{H}_{2}{ }^{35} \mathrm{~S}$ oxidation rate and $\mathrm{p}=$ precipitation rate (see Moeslund et al. [1994] for a presentation of the model). Values are presented as mean \pm range $(\mathrm{n}=2)$
Table 1. Calculations of net and gross sulfate reduction rates at 3 sediment depths in sediment from Rømø (model according to Moeslund et al. 1995). $\mathrm{H}_{2} \mathrm{~S}$ reoxidation rates are estimated as the difference between gross and net sulfate reduction rates. Values are calculated from Fig. 9. SRR: sulfate reduction rate

\begin{tabular}{|c|c|c|c|}
\hline & \multicolumn{3}{|c|}{$\begin{array}{c}0 \text { to } 5 \mathrm{~mm} 5 \text { to } 15 \mathrm{~mm} 15 \text { to } 30 \mathrm{~mm} \\
\left(\mathrm{nmol} \mathrm{cm} \mathrm{cm}^{-3} \mathrm{~d}^{-1}\right)\end{array}$} \\
\hline Net SRR & 44 & 48 & 30 \\
\hline Gross SRR & 205 & 221 & 245 \\
\hline $\mathrm{H}_{2} \mathrm{~S}$ reoxidation rate & 161 & 173 & 215 \\
\hline
\end{tabular}

anaerobic sediment increase sediment metabolism by increasing SRR, but from our experiment this seems not to be the case. On the contrary, our observations indicate suppressed importance of SRR in total sediment metabolism, despite the fact that the burrow walls were rich in carbon due to a thick mucus lining. This supports studies by Banta et al. (1999) and Holmer et al. (1997), who showed decreased SRR in sediment inhabited by $A$. marina and dense populations of Capitella capitata, respectively.

Decreased SRR along the burrow wall as a consequence of Arenicola marina activity was confirmed by the 'sandwich' chamber approach. The artificially irrigated burrows replicated the profiles obtained by $A$. marina, and although the set-up ignored crucial parameters for oxygen consumption and diffusion (piston pumping, rhythmical ventilation and wall permeability for oxygen diffusion), it was evident that organic loading from the mucus lining had no significant impact on the level of SRR. The reduction appeared to be caused by an introduction of oxygenated surface water by irrigation, which indicates that irrigation and oxidized conditions reduce the sulfate reducer's competitive ability. Depressed SRR due to increased competition for reduced organic carbon by iron reducers has been shown in slurries and indicated by several studies on natural sediment (Sørensen 1982, Roden \& Wetzel 1996). The decreased SRR was, however, counterbalanced by a suboxic enhancement ca. 5 to $15 \mathrm{~mm}$ from the burrow wall, and resulted in a zero net impact of burrow irrigation on SRR. This peak was not observed in situ, but is often found in surface sediments where they are attributed to optimized conditions with high loading of labile organic matter, low microbial competition and low concentrations of metabolites (Sørensen \& Jørgensen 1987, Hines et al. 1991, Canfield et al. 1993).

Since the burrowing activity decreased SRR and promoted conditions for dissimilative iron reduction by enriching deeper sediment layers with reactive Fe(III), it is likely that the net result of bioturbation on anaero- 
bic carbon degradation is the partitioning of metabolic pathways towards increased importance of dissimilative iron reduction and depressed SRR. So far, microbial $\mathrm{Fe}(\mathrm{III})$ reduction in relation to bioturbation has been quantified in few studies, e.g. in mangrove areas (Kristensen et al. 2000) and salt marshes (Gribsholt et al. 2003), which all support the hypotheses of decreased importance of SRR and increased dissimilative $\mathrm{Fe}(\mathrm{III})$ reduction due to bioturbation. However, partitioning of the electron acceptor has not been measured directly in sediment bioturbated by Arenicola marina, but Banta et al. (1999) observed elevated metabolism and reduced importance of SRR in A. marina sediments, suggesting dissimilative Fe(III) reduction to be important. Our results, with $50 \%$ decreased SRR along the burrow wall and in the feeding funnel combined with elevated Fe(III) concentrations, support the research by other authors (Hines et al. 1997, Banta et al. 1999, Kristensen et al. 2000, Gribsholt et al. 2003), although we did not measure dissimilative Fe(III) reduction. Direct evidence of increased dissimilative $\mathrm{Fe}(\mathrm{III})$ reduction near burrow walls by $100 \%$ was, however, given by Gribsholt et al. (2003), who also calculated dissimilative $\mathrm{Fe}(\mathrm{III})$ reduction to account for 54 to $86 \%$ of total carbon oxidation in the burrow walls. No such measurements have been taken in feeding funnels, but the elevated organic carbon content, increased redox potential and 'flattened' pore water metabolic profiles (Hüttel 1990, Retraubun et al. 1996), combined with increased Fe(III) content and low SRR, most certainly indicate conditions for dissimilative $\mathrm{Fe}(\mathrm{III})$ reduction. However, future research is still needed to support the hypothesis of increased partitioning of electron acceptors due to bioturbation.

\section{Effect of Arenicola marina on the burial of sulfide}

Sediments inhabited by burrowing infauna generally have limited burial of reduced sulfides, due to irrigation and reworking of sediment particles by the infauna (Thamdrup et al. 1992). In spite of the large variation for in situ TRS, it was clear that sulfide had been oxidized along the burrow wall, leading to dissolution of solid sulfur and subsequent loss from the sediment surrounding the burrow wall. This tendency was confirmed by the chamber experiments, where TRS was reduced by up to $28 \%$ near the burrow wall and $17 \%$ in the feeding funnel. The chamber experiments also revealed that sulfide reoxidation was restricted to the sediment in the vicinity of the tail shaft and the feeding funnel and was mediated through irrigation and sediment reworking. The consequence of bioturbation on bulk sediment sulfide burial is a loss of reduced sulfide from the bioturbated zone, since reox- idation surpasses sulfide production. This is typical for microcosm studies and has formerly been observed in laboratory experiments with sediments inhabited by Arenicola marina (Banta et al. 1999). However, sulfide loss is only temporary until a new, but lower, more balanced level is reached. In natural conditions, as in Løgstør Grunde, net sulfide loss from bulk sediment is expected to occur after events with high sulfide production, e.g. increased organic loading at the surface and high temperature, or due to increased biomass of the bioturbating population with season.

In conclusion, the feeding and ventilation activity of Arenicola marina decreases sediment SRR in a narrow 5 to $15 \mathrm{~mm}$ zone along the tail shaft and in the feeding funnel, suggesting that bioturbation in general depresses the importance of SRR for total sediment metabolism. As the same zones were sites of intense reoxidation with reduced solid sulfide content and increased particulate Fe(III), and were rich in organic carbon, it was suggested that a consequence of bioturbation was the increased importance of dissimilative $\mathrm{Fe}(\mathrm{III})$ reduction. However, this hypothesis needs further research.

Acknowledgements. We are grateful to Morten Jepsen, who assisted with field sampling, and Susanne Boeriths, who provided helpful assistance in the laboratory. The project was partly supported by a grant from the Danida Research Council (ref. no. 90884).

\section{LITERATURE CITED}

Aller RC (1988) Benthic fauna and biogeochemical processes in marine sediments: the role of burrow structures. In: Blackburn TH, Sørensen J (eds) Nitrogen cycling in coastal marine environments. John Wiley \& Sons, Chichester, p 301-338

Aller RC, Aller JY (1998) The effect of biogenic irrigation intensity and solute exchanges on diagenetic reaction rates in marine sediments. J Mar Res 56:905-936

Aller RC, Yingst JY (1978) Biogeochemistry of tubedwellings: a study of the sedentary polychaete Amphitrite ornata (Leidy). J Mar Res 36:201-254

Aller RC, Yingst JY (1980) Relationships between microbial distributions and the anaerobic decomposition of organic matter in surface sediments of Long Island Sound, USA. Mar Biol 56:29-42

Andersen FØ, Kristensen E (1988) Oxygen microgradient in the rhizophere of the mangrove Avicennia marina. Mar Ecol Prog Ser 44:201-204

Banta GT, Holmer M, Jensen M, Kristensen E (1999) Effect of two polychaete worms, Nereis diversicolor and Arenicola marina, on aerobic and anaerobic decomposition in a sandy marine sediment. Aquat Microb Ecol 19:189-204

Binnerup SJ, Jensen K, Revsbech NP, Jensen MH, Sørensen J (1992) Denitrification, dissimilatory reduction of nitrate to ammonium, and nitrification in a bioturbated estuarine sediment as measured with ${ }^{15} \mathrm{~N}$ and microsensor techniques. Appl Environ Microbiol 58(1):303-313

Cadée GC (1976) Sediment reworking by Arenicola marina 
on tidal flats in the Dutch Wadden Sea. Neth J Sea Res 10: $440-460$

Canfield DE (1989) Reactive iron in marine sediments. Geochim Cosmochim Acta 53:619-632

Canfield DE, Thamdrup B, Hansen JW (1993) The anaerobic degradation of organic matter in Danish coastal sediments. Geochim Cosmochim Acta 57:3867-3883

Cline JD (1969) Spectrophotometric determination of hydrogen sulfide in natural waters. Limnol Oceanogr 14: $454-458$

Fossing H, Jørgensen BB (1989) Measurement of bacterial sulfate reduction in sediments: evaluation of a single-step chromium reduction method. Biogeochemistry 8:205-222

Furukawa Y, Bentley SJ, Shiller AM, Lavoie DW, van Cappellen P (2000) The role of biologically-enhanced pore water transport in early diagenesis: an example from carbonate sediments in the vicinity of North Key Harbor, Dry Tortugas National Park, Florida. J Mar Res 58:493-522

Gribsholt B, Kostka JE, Kristensen E (2003) The impact of fiddler crabs and plant roots on sediment biogeochemistry in a Georgia salt marsh. Mar Ecol Prog Ser (in press)

Hansen K, King GM, Kristensen E (1996) Impact of the softshell clam Mya arenaria on sulfate reduction in an intertidal sediment. Aquat Microb Ecol 10:181-194

Hines ME, Jones GE (1985) Microbial biogeochemistry and bioturbation in the sediments of Great Bay, New Hampshire. Estuar Coast Shelf Sci 20:729-742

Hines ME, Bazylinski DA, Tugel JB, Lyons WB (1991) Anaerobic microbial biogeochemistry in sediments from two basins in the Gulf of Maine: evidence for iron and manganese reduction. Estuar Coast Shelf Sci 32:313-324

Hines ME, Faganeli J, Planinc R (1997) Sediment anaerobic microbial biogeochemistry in the Gulf of Trieste, northern Adriatic Sea: influence of bottom water oxygen depletion. Biogeochemistry 39:65-86

Holmer M, Forbes VE, Forbes TL (1997) Impact of the polychaete Capitella sp. I on microbial activity in an organicrich marine sediment contaminated with the polycyclic aromatic hydrocarbon fluoranthene. Mar Biol 128: 679-688

Hüttel M (1990) Influence of the lugworm Arenicola marina on porewater nutrient profiles of sand flat sediments. Mar Ecol Prog Ser 62:241-248

Kampichler C, Bruckner A, Kandeler E (2001) Use of enclosed model ecosystems in soil ecology: a bias towards laboratory research. Soil Biol Biochem 33:269-275

Kostka JE, Luther GW III (1994) Partitioning and speciation of solid phase iron in saltmarsh sediments. Geochim Cosmochim Acta 58:1701-1710

Kostka JE, Gribsholt B, Petrie E, Skelton H, Kristensen E (2002) The rates and pathways of carbon oxidation in bioturbated saltmarsh sediments. Limnol Oceanogr 47(1): $230-240$

Kristensen E (2001) Organic matter diagenesis at the oxic/anoxic interface in coastal marine sediments, with emphasis on the role of burrowing animals. Hydrobiologia 426:1-24

Kristensen E, Andersen FØ (1987) Determination of organic

Editorial responsibility: Gary King,

Walpole, Maine, USA carbon in marine sediments: a comparison of two CHNanalyser methods. J Exp Mar Biol Ecol 109:15-23

Kristensen E, Blackburn TH (1987) The fate of organic carbon and nitrogen in experimental marine sediment systems: influence of bioturbation and anoxia. J Mar Res 45: 231-257

Kristensen E, Jensen MH, Andersen TK (1985) The impact of polychaete (Nereis virens Sars) burrows on nitrification and nitrate reduction in estuarine sediments. J Exp Mar Biol Ecol 85:75-91

Kristensen E, Andersen FØ, Holmboe $N$, Holmer $M$, Thongtham N (2000) Carbon and nitrogen mineralization in sediments of the Bangrong mangrove area, Phuket, Thailand. Aquat Microb Ecol 22:199-213

Lovley DR, Phillips EJP (1987) Rapid assay for microbially reducible ferric iron in aquatic sediments. Appl Environ Microbiol 53:1536-1540

Mackin JE, Swider K (1989) Organic matter decomposition pathways and oxygen consumption in coastal marine sediments. J Mar Res 47:681-716

Meyers MB, Powell EN, Fossing H (1988) Movement of oxybiotic and thiobiotic meiofauna in response to changes in pore-water oxygen and sulfide gradients around macroinfauna tubes. Mar Biol 98:395-414

Moeslund LB, Thamdrup B, Jørgensen BB (1994) Sulfur and iron cycling in a coastal sediment: radiotracer studies and seasonal dynamics. Biogeochemistry 27:129-152

Reichardt W (1988) Impact of bioturbation by Arenicola marina on microbiological parameters in intertidal sediments. Mar Ecol Prog Ser 44:149-158

Retraubun AS, Dawson M, Evans SM (1996) The role of the burrow funnel in feeding processes in the lugworm Arenicola marina. J Exp Mar Biol Ecol 202:107-118

Roden EE, Wetzel RG (1996) Organic carbon oxidation and suppression of methane production by microbial Fe(III) oxide reduction in vegetated and unvegetated freshwater wetland sediments. Limnol Oceanogr 41(8): $1733-1748$

Sørensen J (1982) Reduction of ferric iron in anaerobic, marine sediment and interaction with reduction of nitrate and sulfate. Appl Environ Microbiol 43(2):319-324

Sørensen J, Jørgensen BB (1987) Early diagenesis in sediments from Danish coastal waters: microbial activity and Mn-Fe-S geochimistry. Geochim Cosmochim Acta 51: $779-781$

Stookey LL (1970) Ferrozine-a new spectrophotometric reagent for iron. Anal Chem 42:779-781

Thamdrup B, Fossing H, Jørgensen BB (1994) Manganese, iron and sulfur cycling in a coastal marine sediment, Aarhus Bay, Denmark. Geochim Cosmochim Acta 58: $5115-5129$

van Duyl FC, Kop AJ, Kok A, Sandee AJJ (1992) The impact of organic matter and macrozoobenthos on bacterial and oxygen variables in marine sediment boxcosms. Neth J Sea Res 29:343-355

Zebe E, Schiedek D (1996) The lugworm Arenicola marina: a model of physiological adaptation to life in intertidal sediments. Helgol Meeresunters 50:37-68

Submitted: April 4, 2002; Accepted: April 10, 2003

Proofs received from author(s): August 12, 2003 